\title{
Integration of microRNAome, proteomics and metabolomics to analyze arsenic-induced malignant cell transformation
}

\author{
Youyou Zhou ${ }^{1, *}$, Yanfu Wang ${ }^{4, *}$, Juan Su, ${ }^{1, *}$, Zheng Wu ${ }^{2}$, Chao Wang ${ }^{2}$, Weiming \\ Zhong ${ }^{3}$, Xiaomei Liu' ${ }^{2}$, Linhui Cui ${ }^{2}$, Xiaoyu Zhou ${ }^{2}$, Yufang $\mathrm{Ma}^{5}$, Yi Xin ${ }^{5}$, Jianglin \\ Zhang ${ }^{1}$, Lisha $\mathrm{Wu}^{1}$, Xing Hu${ }^{1}$, Xiang Chen ${ }^{1}$, Cong Peng ${ }^{1}$ and MingYang Gao ${ }^{2}$ \\ ${ }^{1}$ Department of Dermatology, Xiangya Hospital, Central South University, Changsha 410008, Hunan, China \\ ${ }^{2}$ Department of Dermatology, The First Affiliated Hospital of Dalian Medical University, Dalian 116011, Liaoning, China \\ ${ }^{3}$ Department of Neurosurgery, Xiangya Hospital, Central South University, Changsha 410008, Hunan, China \\ ${ }^{4}$ Department of Gerontology, The First Affiliated Hospital of Dalian Medical University, Dalian 116011, Liaoning, China \\ ${ }^{5}$ Department of Biochemistry and Molecular Biology, Dalian Medical University, Dalian 116044, Liaoning, China \\ *These authors have contributed equally to this work \\ Correspondence to: Cong Peng, email: pengcongxy@csu.edu.cn \\ MingYang Gao, email: dlgaomingyang@126.com
}

Keywords: arsenic, microRNAome, proteomics, metabolomics, cutaneous squamous cell carcinoma

Received: November 04, 2016

Accepted: April 21, 2017

Published: June 27, 2017

Copyright: Zhou et al. This is an open-access article distributed under the terms of the Creative Commons Attribution License 3.0 (CC BY 3.0), which permits unrestricted use, distribution, and reproduction in any medium, provided the original author and source are credited.

\section{ABSTRACT}

Long-term exposure to arsenic has been linked to tumorigenesis in different organs and tissues, such as skin; however, the detailed mechanism remains unclear. In this present study, we integrated "omics" including microRNAome, proteomics and metabolomics to investigate the potential molecular mechanisms. Compared with non-malignant human keratinocytes (HaCaT), twenty-six miRNAs were significantly altered in arsenic-induced transformed cells. Among these miRNAs, the differential expression of six miRNAs was confirmed using Q-RT-PCR, representing potential oxidative stress genes. Two-dimensional gel electrophoresis (2D-PAGE) and mass spectrometry (MS) were performed to identify the differential expression of proteins in arsenic-induced transformed cells, and twelve proteins were significantly changed. Several proteins were associated with oxidative stress and carcinogenesis including heat shock protein beta-1 (HSPB1), peroxiredoxin-2 (PRDX2). Using ultraperformance liquid chromatography and Q-TOF mass spectrometry (UPLC/Q-TOF MS), 68 metabolites including glutathione, fumaric acid, citric acid, phenylalanine, and tyrosine, related to redox metabolism, glutathione metabolism, citrate cycle, met cycle, phenylalanine and tyrosine metabolism were identified and quantified. Taken together, these results indicated that arsenic-induced transformed cells exhibit alterations in miRNA, protein and metabolite profiles providing novel insights into arsenic-induced cell malignant transformation and identifying early potential biomarkers for cutaneous squamous cell carcinoma induced by arsenic.

\section{INTRODUCTION}

The worldwide metalloid arsenic pollution is a complex global environmental challenge. Humans are frequently exposed to arsenic as a natural environmental pollutant of water, air, soil and food [1]. Several epidemiological studies have associated arsenic exposure with increasing incidence of skin, liver, bladder, and lung cancer $[2,3]$. This issue has been exacerbated by an increment in the use of arsenic-contaminated water, particularly in developing countries [4]. Therefore, inorganic arsenic has been classified as human carcinogen based on strong epidemiological data [5-7]. 
The effects of arsenic exposure on skin have been documented, particular in skin cancer $[8,9]$. Arsenicinduced skin lesions are characteristic by veracious hyperkeratosis and pigmentation disorders [10]. Other skin lesions associated with human arsenic exposure involves Bowen's disease and squamous cell or basal cell carcinoma [11-14]. Sarkar et al. showed that arsenic may exert toxicity via oxidative stress, indicated by related metabolic biomarkers [15]. However, these studies only focused on one or two aspects of arsenic-driven skin carcinogenesis and a global view of arsenic effects is lacking.

MicroRNAs (miRs) are endogenous $22 \mathrm{nt}$ noncoding RNAs that bind to the untranslated region of target mRNAs and regulate messenger translation through mRNA cleavage, translational repression or mRNA destabilization [16-18]. Micro-RNA exerts critical physiological functions [19-31]. Proteins are the primary effector molecules of all living systems, and any adaptive responses to exotic stresses are reflected through alterations in protein activity or content [32]. Metabolic patterns, the endpoints of enzymatic (protein) activity, are the final consequence of biological function and directly indicate aberrant physiological status.

'Omics' technologies, including microRNAome, proteomics and metabolomics, which provide information on global profile, are therefore regarded as powerful tools to investigate toxic responses to environmental pollutant exposure compared with conventional endpoint bioassays [33-35]. In addition, the integration of microRNAome, proteomics and metabolomics profiles may provide increased reliability in interpreting metabolic alterations resulting from certain genes or proteins, enabling further elucidation of the toxicological effects [36]. Although previous reports have addressed the effects of arsenic exposure on skin using high throughput technology [37-43], integrated microRNAome, proteomics and metabolomics profiles to study skin carcinogenesis induced by arsenic have not been reported.

$\mathrm{HaCaT}$ cell lines have been malignant transformed by continuous exposure to environmentally relevant levels of inorganic arsenic (100 nM) for 28 weeks [44]. In the present study, we generated an arsenic-induced cell transformation model, and integrated microRNAome, proteomics, and metabolomics approaches to investigate alterations in the cellular profiles in arsenic-transformed cells (AS-TM), providing important insights into the initial molecular response to arsenic exposure.

\section{RESULTS}

\section{Low dosage of arsenic induces $\mathrm{HaCaT}$ cells malignant transformation}

To achieve oncogenic transformation, HaCaT cells were continuously exposed to a low level $(100 \mathrm{nM})$ of inorganic arsenite. After 28 weeks of continuous arsenic exposure, the arsenic-treated cells (AS-TM) exhibited unique morphological alterations with the frequent occurrence of giant multinuclear cells (Figure 1A), which are common during malignant transformation and in tumors [45]. The AS-TM cell proliferation was significantly promoted after malignant transformation, as shown in Figure 1D. Anchorage-independent growth is a characteristic of transformed cells [45]. To determine whether cells chronically exposed to arsenite acquired this capacity, anchorage-independent growth was examined and the results showed that $\mathrm{HaCaT}$ cells exposed to 100 $\mathrm{nM}$ sodium arsenic could undergo colony growth in agar compared with control cells (Figure 1B and 1C). Therefore, cells chronically exposed to this low level of arsenite acquired a malignant phenotype.

\section{Arsenic exposure induced the differential expression of miRNAs}

To identify the differential expression of miRNAs induced by arsenite, we analyzed RNA from arseniteinduced transformed cells using microarray. The results showed dramatically changes in twenty-six miRNAs in arsenic-treated $\mathrm{HaCaT}$ cells compared with control cells (Figure 2A and 2B). To validate the microarray results, we selected miRNAs with fold differences $>2$ or $<0.5$ with priority verified $\mathrm{p}<0.01$. Six miRNAs were selected for further analysis via q-RT-PCR. The results showed that mir-6739-5p, mir-4521, mir-181b-5p, mir-100-5p and hmir-3919 were up-regulated, while hsa-mir-513a$5 \mathrm{p}$ was down-regulated in arsenic-treated $\mathrm{HaCaT}$ cells (Figure 2C).

\section{Comparative proteome analysis in arsenic- induced transformed cells}

Next, two-dimensional gel electrophoresis (2D-PAGE) coupled to mass spectrometry (MS) was performed to identify the differentially expressed proteins in $\mathrm{HaCaT}$ human keratinocytes following exposure to arsenic. As shown in Figure $3 \mathrm{~A}$ and 3B, more than 200 spots were detected in the 2D maps. Of which, 12 significant differentially expressed spots $(8$ up-regulated and 4 down-regulated) were identified using LC-ESI-LIT-MS/MS, and alterations in some spots in an arsenic treatment time-dependent manner were confirmed by Western blotting (Figure 3D-3E). These molecules, including heat shock protein beta-1 (HSPB1), peroxiredoxin-2 (PRDX2), adenosylhomocysteinase (SAHH), and leukocyte elastase inhibitor (ILEU), were associated with oxidative stress-induced tumorigenesis.

\section{UPLC/Q-TOF MS multivariate statistical analysis}

To examine the products and most downstream representation of cellular processes, cells transformed by 
A

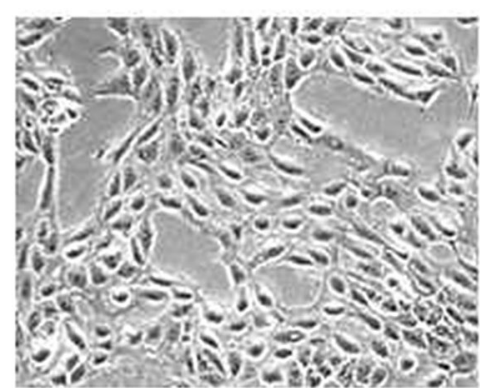

$\mathrm{HaCat}$

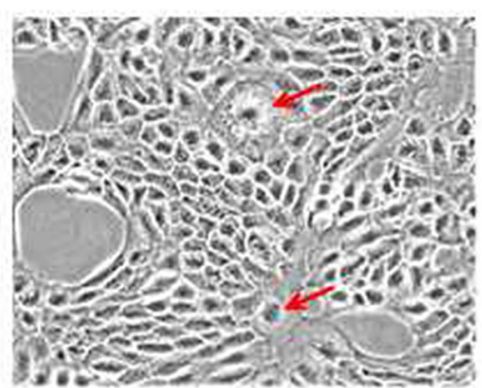

AS-TM

B

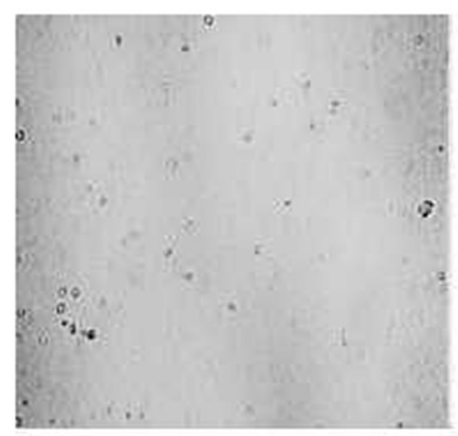

HaCat

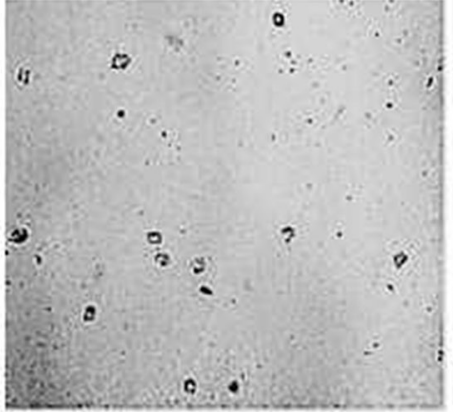

AS-TM
C

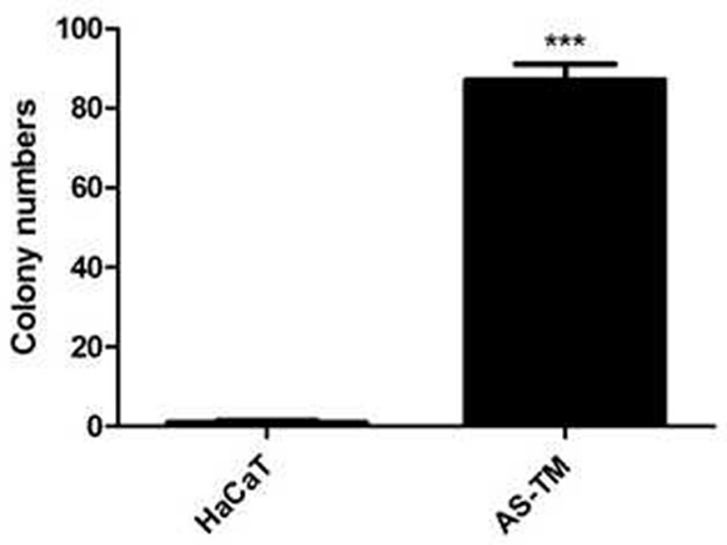

D

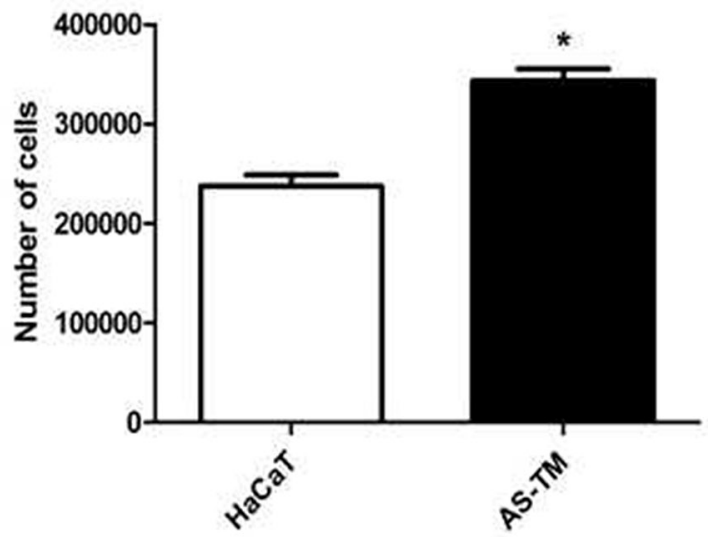

Figure 1: Low-dosage arsenic treatment induces malignant transformation. HaCaT cells were continuously maintained in DMEM medium containing $100 \mathrm{nM}$ of sodium arsenite $\left(\mathrm{NaAsO}_{2}\right)$ for 28 weeks. (A) Morphological alterations in arsenic-exposed cells. The images were captured using a microscope with a camera (200× magnification), and the arrows indicate giant multinuclear cells. (B and C) Colony-formation growth in soft agar. Arsenic-treated and control cells were seeded onto 0.3\% BME agar containing 10\% FBS. The cultures were maintained in a $37^{\circ} \mathrm{C}, 5 \% \mathrm{CO}_{2}$ incubator for 10 days, and subsequently the colonies were counted using a microscope (100× magnification) and the ImageJ computer software program. (D) The number of HaCaT cells compared with arsenic-treated cells at $24 \mathrm{~h}$ after passage (mean \pm SEM, $\mathrm{n}=3$ ), ${ }^{*} \mathrm{p}<0.05$ difference from passage control cells. The data from multiple experiments are expressed as the mean \pm S.D. Significant differences were evaluated using one-way ANOVA, and the respective significant differences are as indicated, $\mathrm{p}<$ 0.001 difference from passage control cells. AS-TM: arsenite-transformed cells. 


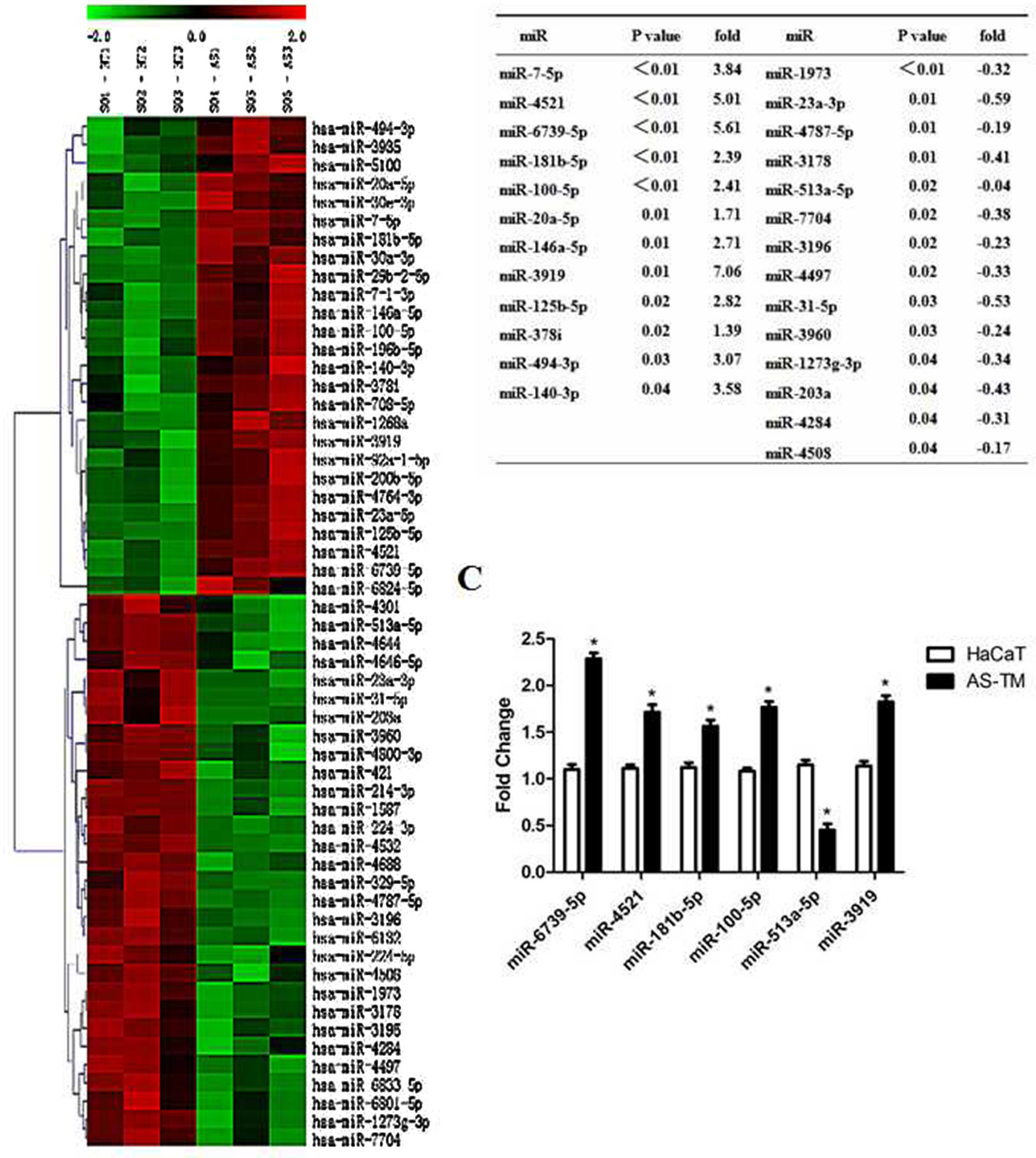

Figure 2: Arsenic exposure induced the differential expression of miRNAs. Total RNAs were extracted from arsenic-induced transformed cells and control cells, and miRNA array was performed for analysis. (A) Hierarchical clustering and heat map of the differential represented miRs in arsenite-treated cells. Gene tree representation (left) and heat maps (right) of miRNAs differentially regulated during arsenite treatment $(\mathrm{T} 1, \mathrm{~T} 2, \mathrm{~T} 3=$ control samples and AS1, AS2, AS3 $=$ arsenite-treated samples) with a p value $\leq 0.05$. Each colored bar represents 1 probe set. Bar colors define the degree of expression (red = over-represented miRs; green = down-represented miRs). (B) List of differentially expressed miRNA in AS-TM cells. (C) Total RNAs were extracted from arsenic-induced transformed and control cells, and q-RT-PCR was performed to test the target gene expression as indicated. Relative expression levels of the six miRs in control (HaCaT) and arsenite-transformed (AS-TM) cells. Each bar represents the mean \pm SEM of three independent replicates. "p value $\leq 0.05$. 


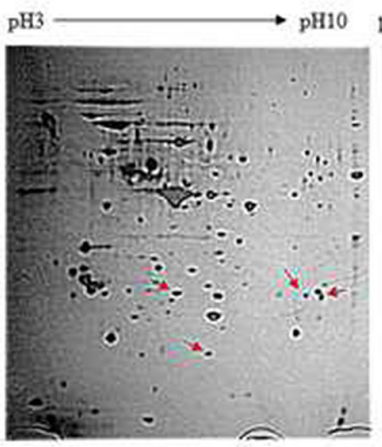

Control

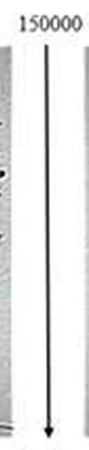

10000

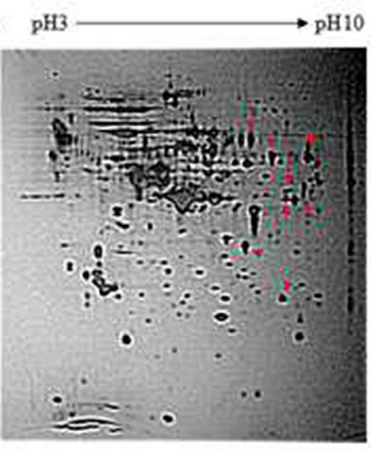

Arsenic

B

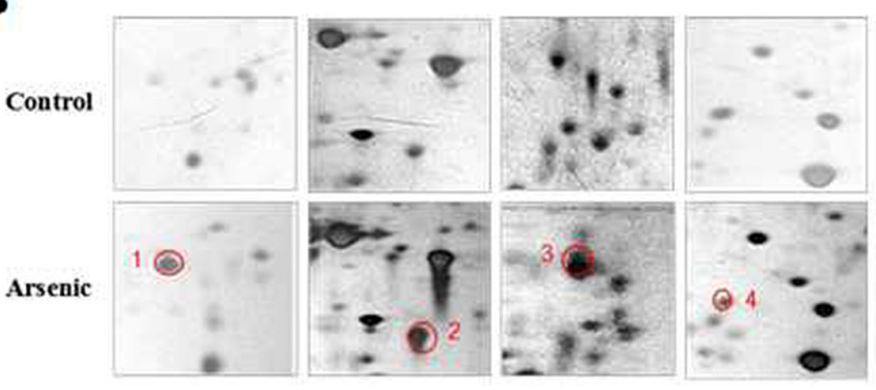

C

\begin{tabular}{|c|c|c|c|c|c|c|}
\hline Spot No. & Description & Score & Mass Mr & $\begin{array}{l}\text { Sequence } \\
\text { Coverage }\end{array}$ & $\begin{array}{c}\text { Calculated } \\
\text { pI value }\end{array}$ & $\begin{array}{l}\text { Expression } \\
\text { inAS-TMI }\end{array}$ \\
\hline 1 & HSPB1_HUALAV(Heat shock protein beta-1) & 248 & 22826 & $29 \%$ & 5.98 & $\uparrow$ \\
\hline 3 & SAHH_HUALAV(Adenosylbomocysteinase) & 47 & 48255 & $6 \%$ & 5.92 & $\uparrow$ \\
\hline 4 & HEU_HUNLAV(Leukocyte elastase inhibitor) & 205 & 42829 & $13 \%$ & 5.90 & $\downarrow$ \\
\hline
\end{tabular}

D

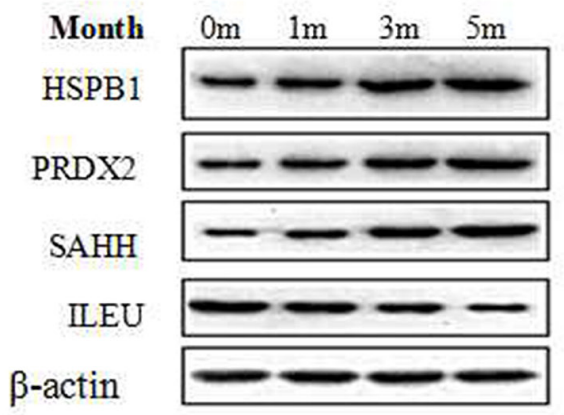

$\mathbf{E}$

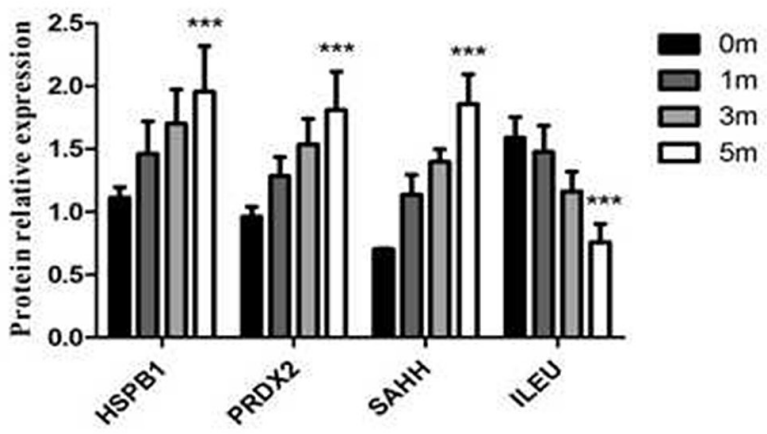

Figure 3: Comparative proteome analysis after arsenic treatment in HaCaT cells. HaCaT cells were continuously maintained in DMEM medium containing $100 \mathrm{nM}$ of sodium arsenite for 28 weeks, and subsequently 2D-PAGE plus MS/MS were performed to analyze the protein expression profile. (A) Representative 2D gel profiles of total proteins (silver staining). The corresponding arrows show the differentially expressed protein spots, where the left four arrows are the up-regulated protein spots in the control group, and the right eight arrows are the up-regulated protein spots in the arsenic treated group. The details of 2-DE procedure are described in the Materials and Methods section. (B) Magnification shows the differentially expressed proteins. (C) The differential expression of protein spots was identified using mass spectrometry, and the MS/MS procedure is described as in the Materials and Methods section. (D) The protein levels of HSPB1, PRDX2, SAHH and ILEU were detected using Western blotting. Relative expression levels of HSPB1, PRDX2, SAHH and ILEU in control (0 month) and at different time points (1, 3 and 5 months) of arsenic treatment in HaCaT cells. (E) Histograms showing the relative fold-change of HSPB1, PRDX2, SAHH and ILEU protein (mean \pm SEM of triplicates) using $\beta$-actin as a control for protein loading. ${ }^{* * *} \mathrm{p}<0.001$ vs. Control. 
arsenic were analyzed using UPLC/Q-TOF MS. PCA was initially performed on the datasets to visualize general clustering trends among the observations. Using a PCA score plot (Figure 4A), two principal components (PC), $\mathrm{R}^{2} \mathrm{X}=0.766$ and $\mathrm{Q}^{2}=0.588$ were obtained in positive ESI mode, and $\mathrm{R}^{2} \mathrm{X}=0.632$ and $\mathrm{Q}^{2}=0.361$ were obtained in negative ESI mode. In general, an $\mathrm{R}^{2} \mathrm{X}$ value greater than 0.4 indicates that the model was reliable, thus the model established in this experiment can be applied to visually observe the difference between the two groups of metabolic profiles. The PCA showed no abnormal samples (all samples were within the confidence interval). Therefore, a PLS-DA model was used to further identify the differences among different groups. The parameter $\mathrm{R}^{2} \mathrm{Y}$ represented the interpretation rate of the model, and $\mathrm{Q}^{2}$ represented the prediction rate of the model. Generally, the reliable model requires a parameter greater than 0.4. The results showed that two principal components obtained in positive and negative modes, respectively $\left(\mathrm{R}^{2} \mathrm{X}=0.749, \mathrm{R}^{2} \mathrm{Y}=0.996, \mathrm{Q}^{2}=0.986\right.$ in positive ESI mode, and $R^{2} \mathrm{X}=0.612, \mathrm{R}^{2} \mathrm{Y}=0.98, \mathrm{Q}^{2}=0.947$ in negative ESI mode) (Figure 4B). Furthermore, the OPLS model was obtained after filtering the orthogonal signal with the model uncorrelated signal. The results showed that one principal component and one orthogonal component were obtained in positive and negative modes, respectively $\left(\mathrm{R}^{2} \mathrm{X}=0.749, \mathrm{R}^{2} \mathrm{Y}=0.996, \mathrm{Q}^{2}=0.986\right.$ in positive ESI mode, and $\mathrm{R}^{2} \mathrm{X}=0.612, \mathrm{R}^{2} \mathrm{Y}=0.98, \mathrm{Q}^{2}=0.995$ in negative ESI mode) (Figure 4C).

\section{Metabolic biomarker screening and identification}

The extracted variables that contributed the most to group distinctions were selected as the biomarkers for arsenic exposure. Strict criteria were adopted for screening: (1) variables with a variable importance in the projection (VIP) value $>1$ were included in the superset of biomarkers; (2) the difference in the candidate level was statistically significant ( $p<0.05$, t-test) between the control and treatment groups; and (3) the online database (http:// metlin.scripps.edu/) (more accurate molecular mass) was searched to characterize differential metabolites. Following these criteria, 68 altered metabolites were identified and considered as potential biomarkers (Figure 4D) (Tables 1 and 2), among, which 27 metabolites were increased, while 41 were decreased after arsenic treatment.

The metabolic pathways involved in the differential metabolites were analyzed using the Reactome Pathway Database (http://www.reactome.org/). The software generated 26 metabolic pathways considered significantly associated with arsenic-induced metabolic changes. These 26 pathways were characterized as redox metabolism, beta-alanine metabolism, citrate cycle (TCA cycle), glutathione metabolism, glycerophospholipid metabolism, nicotinate and nicotinamide metabolism, phenylalanine tyrosine and tryptophan biosynthesis, phenylalanine metabolism, purine metabolism, sphingolipid metabolism, tyrosine metabolism, etc. Briefly, redox metabolism, glutathione metabolism and amino acid biosynthesis and metabolism are the major metabolic pathways disrupted after arsenic exposure.

\section{Molecular networks and metabolism pathways involved in arsenic treatment}

To investigate whether the differential miRNAs, proteins and metabolites interacted biologically, the Reactome Pathway Database (http://www.reactome. org/), KEGG Pathway Database (http://www.genome. jp/kegg/pathway.html), miR2Subpath Database (http://202.97.205.78:8080/miR2Subpath/index.jsp), and TargetScan (www.targetscan.org) software were used to build networks to elucidate the signaling pathways impacted by arsenic in HaCaT. As shown in Figure 5, 14 miRNAs (particularly miR-1273g-3p), 3 proteins (HSPB1, PRDX2 and SAHH) and 5 metabolites (glutathione, $\mathrm{NADP}^{+}$, methionine, PE and PC) were associated with oxidative stress, glutathione metabolism, met cycle and DNA methylation. Furthermore, 11 metabolites were associated with phenylalanine tyrosine and tryptophan biosynthesis and metabolism, nicotinate and nicotinamide metabolism, citrate cycle (TCA cycle) and beta-alanine metabolism, including fumaric acid, malic acid, citric acid, phenylalanine, tyrosine, spermidine, pantothenic acid, phenylacetylglycine, histidine and dopamine. Moreover, glutathione metabolism is the key pathway of this network, suggesting the critical role of redox in the arsenic-induced malignant transformation of human keratinocytes.

\section{DISCUSSION}

Arsenic (As) is a widely distributed environmental toxicant that causes skin cancer [45]. The types of skin cancer associated with arsenic include intraepidermal carcinomas (Bowen disease) [46], squamous cell carcinomas (SCC), basal cell carcinomas (BCC) [47], Merkel cell carcinoma (MCC) [48] and head and neck cancers [49]. Microarray gene expression has revealed that arsenic impacts the function of diverse tissue types, including the skin [50, 51], bladder and kidney [52], liver [53], prostate and lung [54], peripheral lymphocytes [55], neural tube [56], and urogenital cells [57]. HaCaT cells are non-tumor-derived immortalized normal human keratinocytes cell lines with non-tumor properties. Previous studies have confirmed that the continuous exposure of $\mathrm{HaCaT}$ cells to low concentrations of arsenic for approximately 28 weeks induces malignant transformation, manifested as the formation of multinucleated giant cells and highly aggressive squamous cell carcinoma after inoculation into nude mice, indicating that these cells obtain a high degree of malignant phenotypes [58-61]. 
A

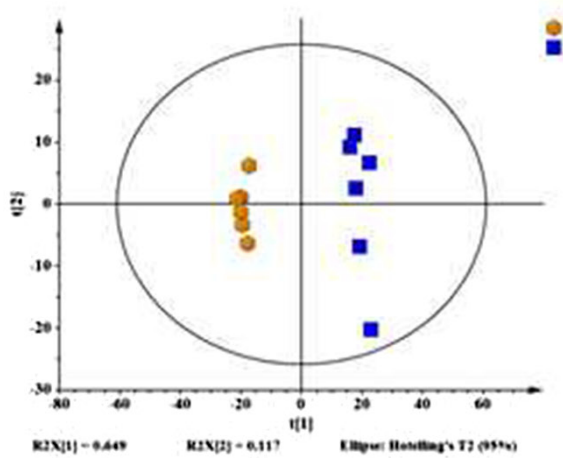

B

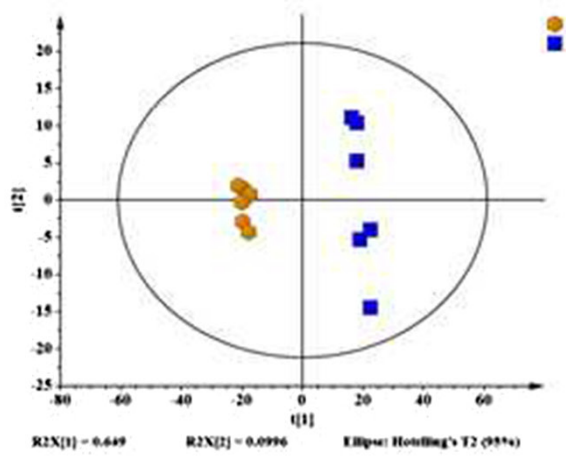

C

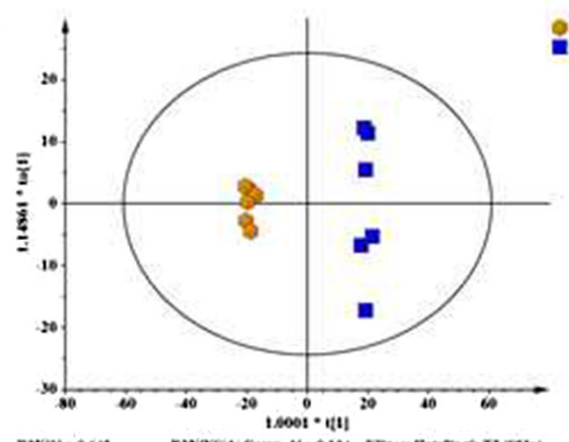

axs

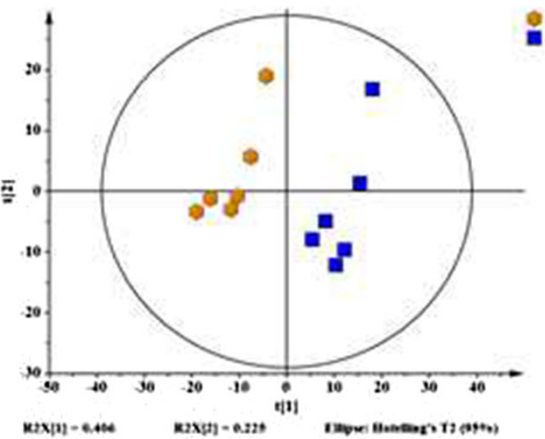

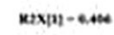

$\cos x=-2 x$

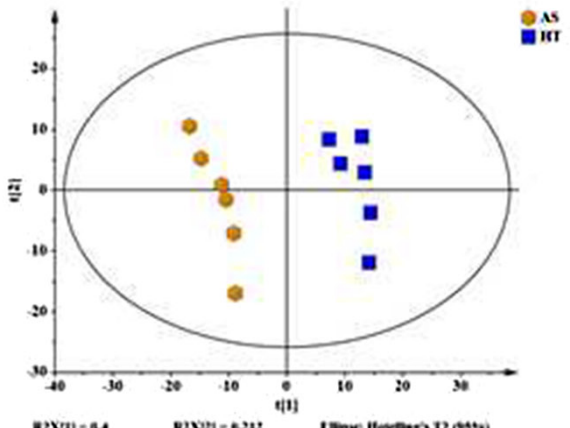

mxpm-as

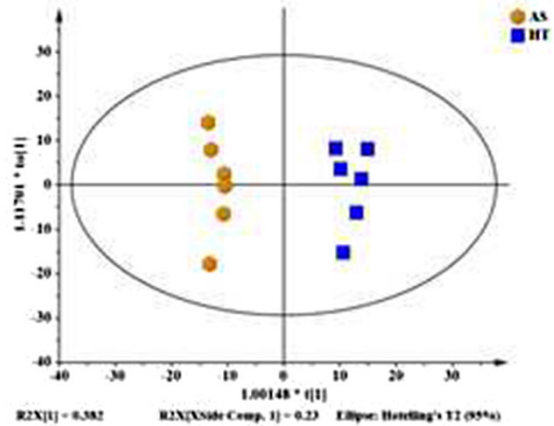

D

Percentage of metabolites

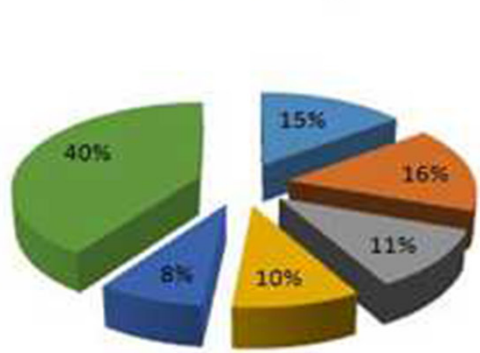

metabolism of lipids and

lipoproteins

a metabolism of amino acids and derivatives

netabolism of

nucleotides

Etransmembrane transport

of small molecules

e signal Transduction

E others

Figure 4: Scoring plots with PCA, PLS-DA and OPLS models of metabolites in control (HT, blue) and arsenic treatment (AS, yellow). (A) PCA for the positive model (Left panel); PCA for the negative model (Right panel). (B) PLS-DA for the positive model (Left panel); PLS-DA for the negative model (Right panel). (C) OPLS for the positive model (Left panel); OPLS for the negative model (Right panel). (D) The overview shows the differential metabolites in arsenic-induced transformed cells compared with control cells. 
Table 1: Differential metabolites in HaCaT exposed to arsenic (ESI+)

\begin{tabular}{|c|c|c|c|c|c|}
\hline VIP & {$[\mathrm{H}+] \mathrm{mz}$} & rt (min) & Name & ttest & fold (AS/HT) \\
\hline 1.114 & 204.1230 & 0.75 & Acetylcarnitine & 0.000 & -2.400 \\
\hline 1.061 & 146.1158 & 3.65 & Acetylcholine & 0.000 & -1.432 \\
\hline 1.071 & 268.1043 & 1.10 & Adenosine & 0.000 & -2.029 \\
\hline 1.173 & 305.2477 & 13.37 & Arachidonic Acid & 0.000 & -4.060 \\
\hline 1.227 & 304.2616 & 13.41 & Arachidonoyl amine & 0.000 & 4.840 \\
\hline 1.238 & 335.2948 & 12.96 & $\mathrm{C} 22: 3$ & 0.000 & 7.624 \\
\hline 1.217 & 162.1123 & 0.71 & Carnitine & 0.000 & -1.950 \\
\hline 1.090 & 255.2316 & 13.25 & $\begin{array}{l}\text { cis-9-palmitoleic } \\
\text { acid }\end{array}$ & 0.000 & -2.158 \\
\hline 1.058 & 132.0767 & 0.73 & Creatine & 0.001 & -0.984 \\
\hline 1.219 & 200.2008 & 10.59 & dodecanamide & 0.000 & 3.166 \\
\hline 1.216 & 154.0831 & 1.24 & Dopamine & 0.000 & -2.942 \\
\hline 1.124 & 307.2609 & 0.63 & Eicosatrienoic acid & 0.000 & -0.955 \\
\hline 1.050 & 152.0569 & 1.19 & Guanine & 0.001 & -2.732 \\
\hline 1.040 & 284.0990 & 1.19 & Guanosine & 0.001 & -2.751 \\
\hline 1.001 & 137.0457 & 1.05 & Hypoxanthine & 0.002 & -1.107 \\
\hline 1.151 & 255.0863 & 5.65 & $\begin{array}{l}\text { L-Arginine } \\
\text { phosphate }\end{array}$ & 0.000 & -0.879 \\
\hline 1.236 & 132.1012 & 1.23 & Leucine/Isoleucine & 0.000 & -2.357 \\
\hline 1.230 & 280.2634 & 12.66 & Linoleamide & 0.000 & 4.231 \\
\hline 1.156 & 279.2295 & 0.64 & Linolenic Acid & 0.000 & -1.151 \\
\hline 1.201 & 150.0583 & 1.05 & Methionine & 0.000 & -3.080 \\
\hline 1.056 & 664.1165 & 1.05 & NAD & 0.001 & -1.513 \\
\hline 1.219 & 282.2808 & 13.41 & Oleamide & 0.000 & 2.667 \\
\hline 1.230 & 256.2639 & 13.16 & Palmitic amide & 0.000 & 3.979 \\
\hline 1.210 & 254.2480 & 12.28 & Palmitoleamide & 0.000 & 4.255 \\
\hline 1.159 & 220.1178 & 2.66 & Pantothenic Acid & 0.000 & -3.051 \\
\hline 1.086 & 496.3400 & 10.99 & $\mathrm{PC}(16: 0)$ & 0.000 & -1.805 \\
\hline 1.083 & 518.3217 & 10.99 & $\mathrm{PC}(18: 3)$ & 0.000 & -1.767 \\
\hline 1.033 & 526.2929 & 10.41 & $\operatorname{PE}(22: 6)$ & 0.001 & -2.555 \\
\hline 1.144 & 194.0811 & 5.12 & Phenylacetylglycine & 0.000 & -4.265 \\
\hline 1.226 & 166.0857 & 2.07 & Phenylalanine & 0.000 & -2.569 \\
\hline 1.156 & 318.2999 & 8.40 & Phytosphingosine & 0.000 & -2.090 \\
\hline 1.095 & 116.0704 & 0.73 & Proline & 0.000 & -1.067 \\
\hline 1.092 & 146.1650 & 0.60 & Spermidine & 0.000 & -2.636 \\
\hline 1.102 & 302.3055 & 9.26 & Sphinganine & 0.000 & -1.804 \\
\hline 1.195 & 300.2899 & 9.58 & Sphingosine & 0.000 & -2.448 \\
\hline 1.009 & 284.2942 & 14.22 & Stearamide & 0.001 & 3.746 \\
\hline 1.197 & 205.0972 & 3.84 & Tryptophan & 0.000 & -2.670 \\
\hline 1.201 & 182.0812 & 1.10 & Tyrosine & 0.000 & -2.737 \\
\hline 1.236 & 118.0864 & 1.05 & Valine & 0.000 & -2.501 \\
\hline 1.174 & 153.0420 & 1.06 & Xanthine & 0.000 & 1.819 \\
\hline
\end{tabular}

Fold (AS/HT) represents the relative level of the metabolite abundance in the arsenic treated group. A positive sign indicates a rise in the arsenic treated group (AS) relative to the control group (HT), with a negative sign indicating a decrease. 
Table 2: Differential metabolites in HaCaT exposed to arsenic (ESI-)

\begin{tabular}{|c|c|c|c|c|c|}
\hline VIP & [H-]mz & rt (min) & Name & ttest & fold (AS/HT) \\
\hline 1.001 & 131.0705 & 4.65 & 2-Hydroxycaproic acid & 0.035 & 0.688 \\
\hline 1.097 & 322.0446 & 0.71 & 5'-CMP & 0.017 & 2.172 \\
\hline 1.455 & 338.9895 & 0.86 & D-Fructose 1,6-bisphosphate & 0.000 & 1.691 \\
\hline 1.409 & 303.2339 & 13.39 & Arachidonic Acid & 0.000 & 1.375 \\
\hline 1.051 & 242.0802 & 0.71 & Cytidine & 0.008 & 1.102 \\
\hline 1.357 & 346.0570 & 0.75 & $\begin{array}{c}\text { deoxyguanosine } \\
\text { 5'-monophosphate (dGMP) }\end{array}$ & 0.001 & 1.585 \\
\hline 1.439 & 498.9073 & 0.61 & D-myo-Inositol-tetraphosphate & 0.000 & -1.243 \\
\hline 1.306 & 115.0036 & 0.76 & Fumaric acid & 0.002 & -1.051 \\
\hline 1.044 & 306.0775 & 0.76 & Glutathione & 0.026 & 1.163 \\
\hline 1.176 & 214.0494 & 0.70 & Glycerylphosphorylethanolamine & 0.009 & 1.749 \\
\hline 1.178 & 362.0516 & 0.76 & $\begin{array}{l}\text { Guanidylic acid (guanosine } \\
\text { monophosphate) }\end{array}$ & 0.001 & 1.451 \\
\hline 1.284 & 282.0854 & 1.19 & Guanosine & 0.003 & -1.951 \\
\hline 1.306 & 154.0624 & 0.68 & Histidine & 0.002 & -0.978 \\
\hline 1.491 & 186.1141 & 5.22 & KAPA & 0.000 & 1.672 \\
\hline 1.018 & 526.2943 & 10.68 & LysoPE(22:5) & 0.031 & -1.211 \\
\hline 1.259 & 133.0104 & 0.76 & Malic acid & 0.003 & -0.880 \\
\hline 1.055 & 194.0829 & 9.88 & n-acetyldopamine & 0.024 & 0.389 \\
\hline 1.339 & 742.0681 & 1.06 & NADP+ & 0.001 & 0.772 \\
\hline 1.220 & 281.2493 & 14.16 & Oleic Acid & 0.005 & 0.946 \\
\hline 1.468 & 218.1041 & 2.66 & Pantothenic Acid & 0.000 & -2.145 \\
\hline 1.175 & 524.2792 & 10.42 & $\operatorname{PE}(22: 6)$ & 0.009 & -1.454 \\
\hline 1.479 & 192.0673 & 5.12 & Phenylacetylglycine & 0.000 & -3.805 \\
\hline 1.040 & 176.9365 & 0.73 & Pyrophosphate & 0.026 & 1.011 \\
\hline 1.271 & 606.0748 & 0.86 & UDP-N-acetyl-D-galactosamine & 0.003 & 2.880 \\
\hline 1.256 & 402.9958 & 0.89 & Uridine diphosphate & 0.004 & 1.144 \\
\hline 1.379 & 323.0297 & 1.05 & Uridine monophosphate (UMP) & 0.000 & 1.226 \\
\hline 1.106 & 151.0266 & 1.06 & Xanthine & 0.000 & 1.896 \\
\hline 1.042 & 179.0566 & 0.69 & $\alpha$-D-Glucose & 0.026 & -0.811 \\
\hline
\end{tabular}

Fold (AS/HT) represents the relative level of the metabolite abundance in the arsenic treated group. A positive sign indicates a rise in the arsenic treated group (AS) relative to the control group (HT), with a negative sign indicating a decrease.

Pi et al. [62] showed that HaCaT cells exposed to low concentrations $(100 \mathrm{nM})$ of sustained excessive arsenic trioxide show abnormal cell proliferation, morphological changes, apoptosis resistance, increased cloning, and uncontrolled cell growth. Sun et al. [63] confirmed that $\mathrm{HaCaT}$ cells exposed to the same concentration of arsenic for 20 weeks showed multinucleated giant cell formation and increased clonogenic formation, indicating that $\mathrm{HaCaT}$ cells exposed to arsenic for 20 weeks undergo malignant transformation. Arsenic induces a highly malignant cell phenotype and arsenic poisoning, replicating most common skin squamous cell populations. Arsenic-induced $\mathrm{HaCaT}$ cells acquire a malignant phenotype and can be used to simulate arsenic-induced skin malignancy. The molecular 
mechanism of arsenic-induced skin cancer using this $\mathrm{HaCaT}$ cell malignant phenotype as a cellular model has been recognized. Clearly, arsenic affects diverse tissue types. However, currently, there are no reports on the combined microRNAome, proteomics and metabolomics analyses of arsenic-induced malignant transformation of HaCaT cells, thus an understanding of the molecular mechanisms of arsenic-induced cancers in diverse tissue types is needed. Therefore, here we established an arsenicinduced $\mathrm{HaCaT}$ cell model based on the results of previous studies for the experimental group, and used normal $\mathrm{HaCaT}$ cells as a control group. Notably, the arsenic concentration used in the present study was comparable to human the blood arsenic levels observed in chronic arsenosis patients in Inner Mongolia, China, where arsenicinduced skin lesions and cancers are common [64]. A combined approach of microRNAome, proteomics, and metabolomics profiling was used to determine alterations in the levels of miRNAs, proteins and metabolic substances in $\mathrm{HaCaT}$ keratinocytes in response to arsenic exposure.

MiRNAs are a large family of endogenously produced short single-stranded (approximately 22 nucleotides) non-coding RNA molecules transcribed in animals, plants and some viruses, which suppress target gene translation through binding to mRNA [65]. In addition, miRNAs served as versatile gene expression regulators in virtually all cellular pathways in higher eukaryotes, including proliferation, apoptosis, cell differentiation, cell cycle, embryonic development and cellular disease $[66,67]$. Additionally, miRNA expression is altered in cancer emergence and metastatic occurrences, therefore playing a pivotal role in health and disease [65]. In the present study, HaCaT cells exposed to $100 \mathrm{nM}$ arsenite for 28 weeks were identified as malignant based on the observation of anchorage-independent growth. Moreover, giant multinuclear cells were observed during the transformation. MiRNA microarray was used to screen differentially expressed miRNAs in two groups of cells, and the results revealed a total of 26 miRNAs (12 upregulated and 14 down-regulated) differentially expressed in arsenic-treated cells compared to untreated controls. Among of these miRNAs, mir-4521, mir-181b-5p, mir100-5p and mir-3919 were significantly up-regulated, and mir-513a-5p was down-regulated. Additional findings confirmed that these six miRNAs were indeed up-regulated and down-regulated in arsenic-stimulated keratinocytes according to quantitative PCR assay. These results suggest that arsenic induced the differential expression of miRNAs during the malignant transformation of $\mathrm{HaCaT}$ cells, and miRNAs may be involved in the carcinogenesis and development of arsenic-induced skin diseases.

As a next step, we investigated the protein expression profile using high-resolution 2-DE combined MS and confirmed heat shock protein beta-1 (HSPB1), peroxiredoxin-2 (PRDX2), adenosylhomocysteinase $(\mathrm{SAHH})$, and leukocyte elastase inhibitor (ILEU) were dramatically changed in arsenic-induced transformed cells. The majority of the identified proteins were associated with antioxidation and tumorigenesis.

Heat shock protein $27 \mathrm{kDa}$ (HSPB1) is associated with stress responses and is typically expressed during tissue remodeling. The major function of this protein is to stabilize protein structure, and HSPB1 is also involved in decreasing the intracellular reactive oxygen species (ROS) in a glutathione-dependent manner [68]. Thus, HSPs in particular, play a protective role against the deleterious effects of redox imbalance observed when ROS production exceeds scavenging mechanisms. HSPB1 is implicated in maintaining the equilibrium or redox homeostasis by maintaining the level of glutathione, a major redox mediator [69]. Aldrian et al. [70] confirmed that HSPB1 inhibits the proliferation of malignant melanoma cells and reduces the tumorigenicity of malignant melanoma cells in nude mice, suggesting that HSPB1 may affect the tumor cell phenotype. Li GP et al. [71] reported that the expression of HSPB1 was associated with nasopharyngeal carcinoma cell differentiation programs, and HSPB1 was highly expressed in poorly differentiated cancer cells. Moreover, the high expression of NF- $\kappa \mathrm{B}$ and MMPs has also been demonstrated in poorly differentiated nasopharyngeal carcinoma cell lines with high expression of HSPB1, suggesting that HSPB1 might enhance the invasion, proliferation and migration of nasopharyngeal carcinoma cells through the activation of the NF-KB signaling pathway and increased expression of MMPs.

Peroxiredoxin-2 (PRDX2) belongs to a superfamily of antioxidant proteins. Johnson et al. [69] showed that the quantitative modeling of $\mathrm{H}_{2} \mathrm{O}_{2}$ metabolism in GPxdeficient mouse erythrocytes required a substantial but not over-whelming contribution of PRDX2. Low et al. [72] confirmed the relevance of PRDX2 in $\mathrm{H}_{2} \mathrm{O}_{2}$ consumption in human erythrocytes. PRDX2 also protects hemoglobin against aggregation [73] and binds many proteins, some of which are bound in a redox-dependent manner [74-77]. A number of recent studies have shown that PRDX2 is involved in tumor proliferation and differentiation [78], associated with signaling pathways within apoptotic cells [79]. Noh et al. [80] showed that PRDX2 overexpression in breast cancer may be associated with the occurrence and development of tumors.

Adenosylhomocysteinase (SAHH) is a conserved enzyme that catalyzes the hydrolysis of S-adenosylhomocysteine (SAH) to adenosine (Ado) and homocysteine (Hcy) in eukaryotes. This conversion is the main route for the breakdown of SAH as a product inhibitor of S-adenosylmethionine (SAM)-dependent methylation reactions. The inhibition of this enzyme increases SAH accumulation, inhibiting the methylation pathway via a feedback inhibition mechanism. In 2008, SAHH was identified as a novel tumor suppressor using genome-wide loss-of-function genetic screening and its down-regulation at mRNA and protein levels was 


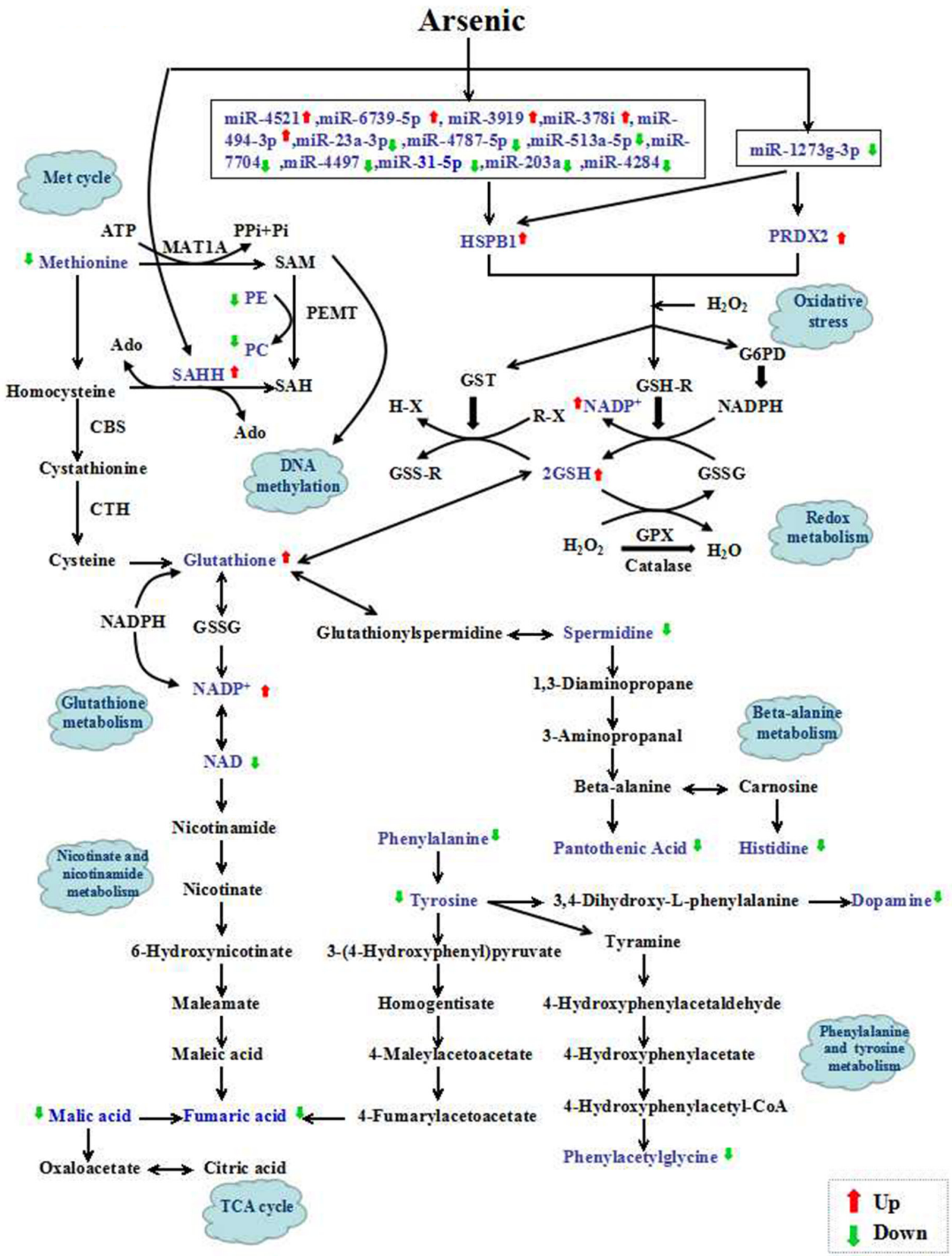

Figure 5: Schematic overview of the integrated the microRNAome, proteomics and metabolomics data to analyze arsenic-induced malignant transformation. The metabolites identified in the present study are highlighted in blue. The up- and downregulation of metabolites is shown with red and green arrows, respectively. $\mathrm{GSH}=$ glutathione; $\mathrm{G} 6 \mathrm{PD}=$ glucose-6-phosphate dehydrogenase; $\mathrm{GST}=$ glutathione transferase; GPX=glutathione peroxidase; $\mathrm{GSSG}=$ oxidized GSH; $\mathrm{CBS}=$ cystathionine $\beta$-synthase; $\mathrm{CTH}=$ cystathionine $\beta$-lyase; $\mathrm{PPi}=$ pyrophosphate; $\mathrm{Pi}=$ inorganic $\mathrm{P} ; \mathrm{SAM}=\mathrm{S}$-adenosylmethionine; $\mathrm{PE}=$ phosphatidylethanolamine; $\mathrm{PC}=$ phosphatidylcholine; $\mathrm{SAH}=$ S-adenosylhomocysteine; Ado = adenosyl; PEMT=phosphatidylethanolamine methyltransferase . 
detected in a considerable percentage of different tumor types, including colon and lung cancers [81]. However, as a novel tumor suppressor gene, SAHH overexpression in skin squamous cell carcinoma has not been reported. In the present study, SAHH was associated with DNA methylation and glutathione metabolism.

Leukocyte elastase inhibitor (ILEU), also known as SERPINB1, has been associated with the occurrence and development of various tumors. Chou and others have shown that SERPINB1 may play a role as a tumor suppressor in breast and lung cancers [82].

Oxidative stress occurs when an imbalance exists between the production of reactive oxygen metabolites and the neutralizing availability of antioxidants. Some wellestablished antioxidants include glutathione, superoxide dismutase (SOD), and vitamins A and E. Heavy metals could cause oxidative stress by disturbing the balance of free radicals [83]. Many metals and metalloids can trigger reactive oxygen species (ROS) production, disrupt signal transduction, alter gene expression, and induce lipid and deoxyribonucleic acid (DNA) damage [84]. Major Asinduced ROS include superoxide anion $\left(\mathrm{O}_{2}{ }^{\bullet-}\right)$, hydroxyl radical $\left({ }^{\bullet} \mathrm{OH}\right)$, hydrogen peroxide $\left(\mathrm{H}_{2} \mathrm{O}_{2}\right)$, singlet oxygen, and peroxyl radicals. Oxygen-derived radicals are the most important class of radical species generated in living systems as a result of the particular electronic configuration of molecular oxygen, leading to the formation of singlet oxygen through the addition of a single electron. Superoxide anions, resulting from metabolic processes or oxygen "activation" through physical irradiation, are considered "primary" ROS molecules that further interact directly through enzyme-catalyzed or metal-catalyzed processes with other molecules to generate "secondary" ROS products. Reactive oxygen species adversely affect cellular proteins, DNA, and membrane lipids and stimulate an increase in antioxidant defense. Furthermore, As-induced ${ }^{\bullet} \mathrm{OH}$ generation has also been reported in the striatum of rats. Apart from direct evidence of As-induced ROS, indirect evidence has also been reported. Arsenic exposure generates ROS in the cells of fish and mammals [85]. Consistent with previous studies, the data in the present study showed that the miRNAs level of Hsps and protein expression of HSPB1, PRDX2 and $\mathrm{SAHH}$ were up-regulated in a time-dependent manner in $\mathrm{HaCaT}$ cells after exposure to $\mathrm{As}_{2} \mathrm{O}_{3}$ compared with the control $(\mathrm{p}<0.05)$, suggesting that excess ROS is generated in $\mathrm{HaCaT}$ cells under arsenic exposure, and the antioxidant capacity was restrained compared with the control after exposure to arsenic.

Glutathione is the most abundant nonprotein thiol in defense against oxidative stress. The importance of the antioxidant activity of enzymes, such as glutathione peroxidase, during the peripartal period has been well established [86]. The enzyme glutamate-cysteine ligase (GCL) is rate limiting in the synthesis of glutathione, and is detected as a heterodimeric complex comprising a catalytic (GCLC) subunit and modifier (GCLM) subunit. The last step in the synthesis of glutathione is mediated through GSS, which binds glycine to the $\gamma$ glutamylcysteine complex through GCLC [87]. Increased Met bioavailability through Met supplementation can indirectly increase the production of total hepatic glutathione through the transsulfuration pathway [88], and oxidative stress is among the many conditions that could increase GCL activity and GCLC mRNA expression [89]. The results of the present study suggested that HSPB1, PRDX2 and SAHH were associated with glutathione metabolism in the malignant transformation of $\mathrm{HaCaT}$ cells induced by arsenic, and the mechanism of these proteins and the metabolism pathway needs further study.

In conclusion, through a combined microRNAome, proteomics and metabolomic analysis, the present study investigated the effects of arsenic exposure on miRNA and protein expression and metabolic pathways in $\mathrm{HaCaT}$ cells. A series of differential miRNAs, proteins and metabolites particularly associated with oxidative stress was identified. In addition, we suggested that the dysregulation of miRNAs (particularly miR-1273g-3p), proteins (HSPB1, PRDX2 and SAHH) and metabolites (glutathione, NADP + , methionine, PE and PC) induced arsenic prevents oxidative damage, which was involved in the activation of glutathione metabolism pathways (Figure 5). These findings could be extended to more details of networks induced by arsenic and their inference in carcinogenesis, which may provide the foundation for developing better therapeutic strategies.

\section{MATERIALS AND METHODS}

\section{Cell culture and arsenate exposure}

Human keratinocyte HaCaT cells (maintained in the lab) were cultured in DMEM supplemented with $10 \%$ FBS, $100 \mathrm{U}$ of penicillin/ml, and $100 \mathrm{mg}$ of streptomycin/ $\mathrm{ml}$. The cultures were maintained at $37^{\circ} \mathrm{C}$ in a humidified $5 \% \mathrm{CO}_{2}$ atmosphere. The culture media was replaced with fresh growth media every 2-3 days.

For chronic arsenic exposure, the cells were continuously maintained in medium containing $100 \mathrm{nM}$ of sodium arsenite $\left(\mathrm{NaAsO}_{2}\right.$, Sigma, St. Louis, $\left.\mathrm{MO}\right)$ for 28 weeks [44]. All materials for cell culture were purchased from Thermo Scientific HyClone (Logan, UT, USA).

\section{Anchorage-independent growth assay}

The cells $\left(5 \times 10^{3} /\right.$ well $)$ were suspended in $1 \mathrm{~mL}$ of DMED medium supplemented with $10 \%$ FBS and $0.33 \%$ agar, seeded onto $3 \mathrm{~mL}$ of solidified DMED medium supplemented with 10\% FBS and 0.5\% agar in 6-well plates, and subsequently cultured for 3 weeks. The colonies were scored using a microscope and ImageJ computer software. 


\section{Microarray analysis}

Three control samples and three experimental samples were sent to the LC-Bio Company (Beijing, China) for miRNA microarray hybridization and analysis. The miRCURYTM RNA Isolation Kit and the miRCURYTM LNA Array power labeling kit (Exiqon) were used to extract total RNA and label the samples. The samples were subsequently scanned using the Agilent G2565BA Microarray Scanner System (Santa Clara, CA). ImaGene 8.0 software was used for the image analysis (BioDiscovery, Inc., Hawthorne, CA). Normalization was performed using the global Lowess regression algorithm, the original data was shown in Supplementary Table 1.

\section{MiRNAs isolation and cDNA preparation}

To validate the microarray data, a miRNA purification kit (Biosynthesis, Lewisville TX) was used to extract miRNAs from the remaining biological replicates of the untreated control $(\mathrm{N}=3)$ and arsenite-treated $(\mathrm{N}=3)$ samples. Subsequently, cDNA was synthesized for each sample using the miRNA First-Strand synthesis kit following manufacturer's instructions (Clontech, Mountain View, CA).

\section{Quantitative real-time PCR analysis}

MiRNA primers, used to amplify the entire sequence, were designed for the six selected miRNAs (Integrated DNA technologies Inc., Coralville, IA). The miRNA expression was quantified using a SYBR qRTPCR kit (Clontech) and the cDNA from each of the three biological replicates of arsenite-treated $(\mathrm{N}=3)$ and control samples $(\mathrm{N}=3)$. U6 was used as a reference gene. The forward primers were designed and synthesized at the BIONEER Company (Korea), and the reverse primers were provided in the reagent kit. The following forward primers were used:

\begin{tabular}{|c|c|}
\hline miRNA & Sequence \\
\hline mir-181b-5p & $\begin{array}{l}\text { 5'-GCAACATTCATTGCTGTCGG } \\
\text { TGGGT-3' }\end{array}$ \\
\hline $\operatorname{mir}-100-5 p$ & $\begin{array}{l}\text { 5'-GCGCAACCCGTAGATCCGAA } \\
\text { CTTGT-3' }\end{array}$ \\
\hline $\begin{array}{l}\text { mMir-6739- } \\
5 p\end{array}$ & $\begin{array}{l}\text { 5'-GCGCAGTGGGAAAGAG } \\
\text { AAAGAACAAGT-3' }\end{array}$ \\
\hline $\operatorname{mir}-4521$ & $\begin{array}{l}\text { 5'-GCGCTAAGGAAGTCCTGTGC } \\
\text { TCAG-3' }\end{array}$ \\
\hline mir-3919 & $\begin{array}{l}\text { 5'-GGGCAGAGAACAAAGGACT } \\
\text { CAGT-3' }\end{array}$ \\
\hline $\operatorname{mir}-513 a-5 p$ & 5'-GCGTTCACAGGGAGGTGTCAT-3' \\
\hline U6 & $\begin{array}{l}\text { 5'-ACACGCAAATTCGTGAAG } \\
\text { CGTTCC-3' }\end{array}$ \\
\hline
\end{tabular}

\section{Functional clustering of miRNAs putative target}

To obtain a wide view of the potential miRNA targets, we performed an in silico prediction analysis using three distinct software: Miranda (www.microrna.org), TargetScan (www.targetscan.org) and PicTar (www.pictar. org). The target genes, predicted by above-mentioned programs, were matched using MatchMiner software (www.discover.nci.nih.gov/matchminer/index.jsp).

\section{2-DE and image analysis}

Two-dimensional electrophoresis (2-DE) and gelimage analysis were performed as reported in the literature [90]. Briefly, total proteins $(600 \mathrm{mg})$ were loaded onto $24 \mathrm{~cm}$ IPG strips (immobilized pH 4-7; GE Healthcare, Waukesha, WI, USA) by rehydration loading overnight. Isoelectric focusing was performed at $50 \mathrm{~V}$ for $4 \mathrm{~h}$, $100 \mathrm{~V}$ for $1 \mathrm{~h}, 500 \mathrm{~V}$ for $1 \mathrm{~h}, 1000 \mathrm{~V}$ for $1 \mathrm{~h}, 2000 \mathrm{~V}$ for $1 \mathrm{~h}, 4000 \mathrm{~V}$ for $2 \mathrm{~h}, 8000 \mathrm{~V}$ for $5 \mathrm{~h}, 8000 \mathrm{~V}$ for 9 $\mathrm{h}$, and $50 \mathrm{~V}$ for $6 \mathrm{~h}$ using an IPGphor II platform (GE Healthcare). Each focused strip was equilibrated in $5 \mathrm{ml}$ of equilibration buffer containing $6 \mathrm{M}$ urea, $30 \%(\mathrm{v} / \mathrm{v})$ glycerol, 2\% (w/v) SDS, $50 \mathrm{mM}$ Tris- $\mathrm{HCl}(\mathrm{pH} 6.8), 0.1$ $\mathrm{mg} / \mathrm{ml}$ of bromophenol blue, and $100 \mathrm{mM}$ DTT as a first step, and $55 \mathrm{mM}$ iodoacetamide as a second step. The twodimensional separation of proteins was performed on $10 \%$ SDS-PAGE at $2 \mathrm{~W}$ per gel, $500 \mathrm{~V}$, and $300 \mathrm{~mA}$ for 30 min, followed by $16 \mathrm{~W}$ per gel, $700 \mathrm{~V}$, and $300 \mathrm{~mA}$. The gels were stained with colloidal CBB (Coomassie brilliant blue) G-250 staining solution [34\% (v/v) methanol, $17 \%(\mathrm{w} / \mathrm{v})$ ammonium sulfate, $3 \%(\mathrm{v} / \mathrm{v})$ phosphoric acid, and $0.1 \%(\mathrm{w} / \mathrm{v}) \mathrm{CBB}$ G-250] and destained twice with $30 \%(\mathrm{v} / \mathrm{v})$ methanol distilled water. The stained gels were scanned for image analysis using a transmission scanner (PowerLook 1120, UMAX, Dallas, TX, USA) with a 32bit pixel depth and 300 dpi resolution. Protein spots on 2D gels were detected and processed using ImageMaster 2D Platinum software 6.0 (GE Healthcare, Waukesha, WI, USA). The percentage volume of each spot was determined from three biological replicates and the original data was shown in Supplementary Table 2.

\section{Mass spectrometry analysis and protein identification}

The gel spots were excised, S-alkylated, digested with trypsin, and subjected to a desalting/concentration step on $\mu$ ZipTip $\mathrm{C}_{18}$ pipette tips. The samples were subsequently analyzed by nanoLC-ESI-LIT-MS/MS using an LTQ XL mass spectrometer (Thermo, San Jose, CA, USA) equipped with a Proxeon nanospray source connected to an EasynanoLC (Proxeon, Denmark). Peptide mixtures were separated on an Easy $\mathrm{C}_{18}$ column $(100 \times$ $0.075 \mathrm{~mm}, 3 \mu \mathrm{m}$ ) (Thermo, USA) using a acetonitrile gradient containing $0.1 \%$ formic acid in aqueous $0.1 \%$ formic acid; acetonitrile ramped from 5 to $35 \%$ over 
$24 \mathrm{~min}$ and from 35 to $95 \%$ over $2 \mathrm{~min}$, at a flow rate of $300 \mathrm{nl} / \mathrm{min}$. The spectra were acquired in the range of 400-2000 m/z. Acquisition was controlled by a datadependent product ion scanning procedure over the three most abundant ions, enabling dynamic exclusion (repeat count two and exclusion duration $1 \mathrm{~min}$ ). Mass isolation window and collision energy were set to $3 \mathrm{~m} / \mathrm{z}$ and $35 \%$, respectively.

MASCOT 2.3.02 software (Matrix Science, UK) was used to identify spots from a non-redundant human protein database (UniProt nr06/2013, 125229 sequences). NanoLC-ESI-LIT- MS/MS data were searched using a mass tolerance value of $2 \mathrm{Da}$ for precursor ion and 0.8 $\mathrm{Da}$ for MS/MS fragments, with trypsin as the proteolytic enzyme, a missed cleavage maximum value of 2 and Cys carbamidomethylation, pyroglutamate formation at N-terminal Gln, and Met oxidation as fixed and variable modifications, respectively. Protein candidates with more than two unique assigned peptides with an individual MASCOT score $>25$, corresponding to $\mathrm{p} \leq 0.05$ for a significant identification, were further evaluated through comparison with their calculated $\mathrm{Mr}$ and $\mathrm{pI}$ values, using the experimental values obtained from 2-DE.

\section{Immunoblotting}

Immunoblotting was performed as previously described [91]. The following antibodies were used: HSPB1 antibody (Santa Cruz Biotechnology, Santa Cruz, CA, USA), diluted at 1:500; PRDX2 antibody (Santa Cruz Biotechnology), diluted at 1:500; SAHH antibody (Abcam, Cambridge, UK) diluted at 1:1000; and ILEU antibody (Abcam), diluted at 1:1000. The blots were normalized to $\beta$-actin (Cell Signaling Technology, Inc., Beverly, MA). The bands were quantified using ImageJ software (v4.18).

\section{Metabolite analysis by UPLC/Q-TOF MS}

The instrumental analysis platform was UPLC-Q/ TOF-MS (Agilent, 1290 Infinity LC, 6530 UHD and Accurate-Mass Q-TOF/MS). The injection volume was $4 \mu \mathrm{L}$ and the auto-sampler temperature was $4^{\circ} \mathrm{C}$. The processed feature tables were subsequently Paretoscaled and submitted to SIMCA-P V11.5 software (Umetrics, Uppsala, Sweden) for multivariate statistical analysis. Principal component analysis (PCA) was first performed to discover intrinsic treatment-related clusters within the datasets. Subsequently, partial least-squares discriminant analysis (PLS-DA) was used to improve separation among the groups and screen biomarkers, and differentiated metabolites were extracted according to the VIP value of orthogonal partial least squares (OPLS). The levels of metabolites in the arsenic-treated group (AS) and the control group (HT) were compared using the t-test $(p<0.05)$ of the two samples. Fold- $(\mathrm{AS} /$ HT) represents the relative level of the substance in the arsenic-treated group. A positive sign indicates an increase in the AS group relative to the HT group, with a negative sign indicating a decrease. Variable importance in projection (VIP) represents the ability of the extracted variables to discriminate between different groups, and the variables with VIP values greater than 1.0 were included in the preset of biomarkers. The qualitative method of differential metabolites was performed after searching the online database (http://metlin.scripps.edu/) and the original data was shown in Supplementary Table 3.

\section{Statistical analysis}

The data are expressed as the mean \pm SEM. Student's t-test or one-way ANOVA was used to determine the significant differences. $\mathrm{p}<0.05$ was considered statistically significant.

\section{ACKNOWLEDGMENTS}

This work was financially supported by Grant No. 81572679, 81350023, 81472852, 81472882 from the National Natural Science Foundation; Grant No. 2015JJ2161 from Natural Science Foundation of Hunan Province; Grant No. 81430075 from the key project of the National Science Foundation.

\section{CONFLICTS OF INTEREST}

The authors declare that they have no conflicts of interest.

\section{REFERENCES}

1. Hughes MF, Beck BD, Chen Y, Lewis AS, Thomas DJ. Arsenic exposure and toxicology: a historical perspective. Toxicol Sci. 2011; 123:305-332.

2. Hunt KM, Srivastava RK, Elmets CA, Athar M. The mechanistic basis of arsenicosis: pathogenesis of skin cancer. Cancer Lett. 2014; 354:211-219.

3. Frost FJ, Frost FJ. (2004). Cancer risks associated with elevated levels of drinking water arsenic exposure. (Denver, Colo.: AWWA Research Foundation).

4. Nordstrom DK. Public Health. Worldwide Occurrences of Arsenic in Ground Water. Science. 2002; 296:2143-2145.

5. McClintock TR, Chen Y, Parvez F, Makarov DV, Ge W, Islam T, Ahmed A, Rakibuz-Zaman M, Hasan R, Sarwar G, Slavkovich V, Bjurlin MA, Graziano JH, Ahsan H. Association between arsenic exposure from drinking water and hematuria: results from the Health Effects of Arsenic Longitudinal Study. Toxicol Appl Pharm. 2014; 276:21-27.

6. Lan $\mathrm{C}, \mathrm{Yu} \mathrm{H}, \mathrm{Ko}$ Y. Chronic arsenic exposure and its adverse health effects in Taiwan: a paradigm for management of a 
global environmental problem. Kaohsiung J Med Sci. 2011; 27:411-416.

7. Smith AH, Biggs ML, Moore L, Haque R, Steinmaus C, Chung J, Hernandez A, Lopipero P. (1999). Cancer Risks from Arsenic in Drinking Water: Implications for Drinking Water Standards A2 - Chappell, Willard R. In: Abernathy $\mathrm{CO}$ and Calderon RL, ed. Arsenic Exposure and Health Effects III. (Oxford: Elsevier Science Ltd), pp. 191-199.

8. Zhuang W, Gao X. Distributions, sources and ecological risk assessment of arsenic and mercury in the surface sediments of the southwestern coastal Laizhou Bay, Bohai Sea. Mar Pollut Bull. 2015; 99:320-327.

9. Rasool A, Farooqi A, Xiao T, Masood S, Kamran MA, Bibi S. Elevated levels of arsenic and trace metals in drinking water of Tehsil Mailsi, Punjab, Pakistan. J Geochem Explor. 2016; 169:89-99.

10. Yang L, Chai Y, Yu J, Wei B, Xia Y, Wu K, Gao J, Guo Z, Cui N. Associations of arsenic metabolites, methylation capacity, and skin lesions caused by chronic exposure to high arsenic in tube well water. Environ Toxicol. 2017; 32:28-36.

11. Maiti S. (2015). 9 - Arsenic-Induced Mutagenesis and Carcinogenesis: A Possible Mechanism A2 - Flora, S.J.S. Handbook of Arsenic Toxicology. (Oxford: Academic Press), pp. 233-279.

12. Wong SS, Tan KC, Goh CL. Cutaneous manifestations of chronic arsenicism: review of seventeen cases. J Am Acad Dermatol. 1998; 38:179-185.

13. Germolec DR, Spalding J, Yu H, Chen GS, Simeonova PP, Humble MC, Bruccoleri A, Boorman GA, Foley JF, Yoshida T, Luster MI. Arsenic enhancement of skin neoplasia by chronic stimulation of growth factors. Am J Pathol. 1998; 153:1775-1785.

14. Waalkes MP, Liu J, Ward JM, Diwan BA. Animal models for arsenic carcinogenesis: inorganic arsenic is a transplacental carcinogen in mice. Toxicol Appl Pharm. 2004; 198:377-384.

15. Sarkar S, Mukherjee S, Chattopadhyay A, Bhattacharya S. Differential modulation of cellular antioxidant status in zebrafish liver and kidney exposed to low dose arsenic trioxide. Ecotox Environ Safe. 2017; 135:173-182.

16. Bartel DP. MicroRNAs: target recognition and regulatory functions. Cell. 2009; 136:215-233.

17. Bao W, Greenwold MJ, Sawyer RH. Expressed miRNAs target feather related mRNAs involved in cell signaling, cell adhesion and structure during chicken epidermal development. Gene. 2016; 591:393-402.

18. Krishnan K, Askew DS. Endoplasmic reticulum stress and fungal pathogenesis. Fungal Biol Rev. 2014; 28:29-35.

19. Esau C, Davis S, Murray SF, Yu XX, Pandey SK, Pear M, Watts L, Booten SL, Graham M, McKay R, Subramaniam A, Propp S, Lollo BA, et al. miR-122 regulation of lipid metabolism revealed by in vivo antisense targeting. Cell Metab. 2006; 3:87-98.
20. Ong S, Lee WH, Kodo K, Wu JC. MicroRNA-mediated regulation of differentiation and trans-differentiation in stem cells. Adv Drug Deliver Rev. 2015; 88:3-15.

21. Massart J, Katayama M, Krook A. microManaging glucose and lipid metabolism in skeletal muscle: role of microRNAs. Biochim Biophys Acta. 2016; 1861:2130-2138.

22. Lazare SS, Wojtowicz EE, Bystrykh LV, de Haan G. microRNAs in hematopoiesis. Exp Cell Res. 2014; 329:234-238.

23. Tran TH, Montano MA. (2017). Chapter 1 - MicroRNAs: Mirrors of Health and Disease A2 - Laurence, Jeffrey. Translating Micrornas to the Clinic. (Boston: Academic Press), pp. 1-15.

24. Bloomston M, Frankel WL, Petrocca F, Volinia S, Alder H, Hagan JP, Liu CG, Bhatt D, Taccioli C, Croce CM. MicroRNA expression patterns to differentiate pancreatic adenocarcinoma from normal pancreas and chronic pancreatitis. JAMA. 2007; 297:1901-1908.

25. Schetter AJ, Leung SY, Sohn JJ, Zanetti KA, Bowman ED, Yanaihara N, Yuen ST, Chan TL, Kwong DL, Au GK, Liu CG, Calin GA, Croce CM, Harris CC. MicroRNA expression profiles associated with prognosis and therapeutic outcome in colon adenocarcinoma. JAMA. 2008; 299:425-436.

26. Huang X, Ding L, Bennewith KL, Tong RT, Welford SM, Ang KK, Story M, Le QT, Giaccia AJ. Hypoxia-inducible mir-210 regulates normoxic gene expression involved in tumor initiation. Mol Cell. 2009; 35:856-867.

27. Dai L, Lou W, Zhu J, Zhou X, Di W. MiR-199a inhibits the angiogenic potential of endometrial stromal cells under hypoxia by targeting HIF-1alpha/VEGF pathway. Int J Clin Exp Pathol. 2015; 8:4735-4744.

28. Xu S, Zhang R, Niu J, Cui D, Xie B, Zhang B, Lu K, Yu W, Wang X, Zhang Q. Oxidative stress mediated-alterations of the microRNA expression profile in mouse hippocampal neurons. Int J Mol Sci. 2012; 13:16945-16960.

29. Varga ZV, Kupai K, Szucs G, Gaspar R, Paloczi J, Farago N, Zvara A, Puskas LG, Razga Z, Tiszlavicz L, Bencsik $\mathrm{P}$, Gorbe A, Csonka C, et al. MicroRNA-25-dependent up-regulation of NADPH oxidase 4 (NOX4) mediates hypercholesterolemia-induced oxidative/nitrative stress and subsequent dysfunction in the heart. J Mol Cell Cardiol. 2013; 62:111-121.

30. Finger F, Hoppe T. MicroRNAs meet calcium: joint venture in ER proteostasis. Sci Signal. 2014; 7:e11.

31. Byrd AE, Brewer JW. Micro(RNA) managing endoplasmic reticulum stress. IUBMB Life. 2013; 65:373-381.

32. Zhong L, Zhou J, Chen X, Lou Y, Liu D, Zou X, Yang B, Yin Y, Pan Y. Quantitative proteomics study of the neuroprotective effects of B12 on hydrogen peroxideinduced apoptosis in SH-SY5Y cells. Sci Rep. 2016; 6:22635.

33. Huang Q, Zhang J, Martin FL, Peng S, Tian M, Mu X, Shen H. Perfluorooctanoic acid induces apoptosis through the 
p53-dependent mitochondrial pathway in human hepatic cells: a proteomic study. Toxicol Lett. 2013; 223:211-220.

34. Du Z, Zhang Y, Wang G, Peng J, Wang Z, Gao S. TPhP exposure disturbs carbohydrate metabolism, lipid metabolism, and the DNA damage repair system in zebrafish liver. Sci Rep. 2016; 6:21827.

35. Gu J, Hu X, Shao W, Ji T, Yang W, Zhuo H, Jin Z, Huang $\mathrm{H}$, Chen J, Huang C, Lin D. Metabolomic analysis reveals altered metabolic pathways in a rat model of gastric carcinogenesis. Oncotarget. 2016; 7:60053-60073. https:// doi.org/10.18632/oncotarget.11049.

36. Garcia-Sevillano MA, Garcia-Barrera T, Navarro F, GomezAriza JL. Analysis of the biological response of mouse liver (Mus musculus) exposed to As2O3 based on integratedomics approaches. Metallomics. 2013; 5:1644-1655.

37. Amodio G, Sasso E, D'Ambrosio C, Scaloni A, Moltedo O, Franceschelli S, Zambrano N, Remondelli P. Identification of a microRNA (miR-663a) induced by ER stress and its target gene PLOD3 by a combined microRNome and proteome approach. Cell Biol Toxicol. 2016; 32:285-303.

38. Kim S, Lee SH, Lee S, Park JD, Ryu DY. Arsenite-induced changes in hepatic protein abundance in cynomolgus monkeys (Macaca fascicularis). Proteomics. 2014; 14:1833-1843.

39. Chen SH, Wang YW, Hsu JL, Chang HY, Wang CY, Shen PT, Chiang CW, Chuang JJ, Tsai HW, Gu PW, Chang FC, Liu HS, Chow NH. Nucleophosmin in the pathogenesis of arsenic-related bladder carcinogenesis revealed by quantitative proteomics. Toxicol Appl Pharmacol. 2010; 242:126-135.

40. García-Sevillano MÁ, García-Barrera T, Navarro-Roldán F, Montero-Lobato Z, Gómez-Ariza JL. A combination of metallomics and metabolomics studies to evaluate the effects of metal interactions in mammals. Application to Mus musculus mice under arsenic/cadmium exposure. J Proteomics. 2014; 104:66-79.

41. Udensi UK, Tackett AJ, Byrum S, Avaritt NL, Sengupta D, Moreland LW, Tchounwou PB, Isokpehi RD. Proteomicsbased identification of differentially abundant proteins from human keratinocytes exposed to arsenic trioxide. J Proteomics Bioinform. 2014; 7:166-178.

42. Wang X, Mu X, Zhang J, Huang Q, Alamdar A, Tian M, Liu L, Shen H. Serum metabolomics reveals that arsenic exposure disrupted lipid and amino acid metabolism in rats: a step forward in understanding chronic arsenic toxicity. Metallomics. 2015; 7:544-552.

43. Zhang J, Shen H, Xu W, Xia Y, Barr DB, Mu X, Wang X, Liu L, Huang Q, Tian M. Urinary metabolomics revealed arsenic internal dose-related metabolic alterations: a proofof-concept study in a Chinese male cohort. Environ Sci Technol. 2014; 48:12265-12274.

44. Pi J, Diwan BA, Sun Y, Liu J, Qu W, He Y, Styblo M, Waalkes MP. Arsenic-induced malignant transformation of human keratinocytes: involvement of Nrf2. Free Radic Biol Med. 2008; 45:651-658.

45. Schulz EJ. Arsenic as a cause of skin cancer, with notes on its occurrence in Pretoria. S Afr Med J. 1967; 41:819-822.

46. Col M, Col C, Soran A, Sayli BS, Ozturk S. Arsenic-related Bowen's disease, palmar keratosis, and skin cancer. Environ Health Perspect. 1999; 107:687-689.

47. Yu HS, Chen GS, Sheu HM, Kao JS, Chang KL, Yu CL. Alterations of skin-associated lymphoid tissue in the carcinogenesis of arsenical skin cancer. Proc Natl Sci Counc Repub China B. 1992; 16:17-22.

48. Ho SY, Tsai YC, Lee MC, Guo HR. Merkel cell carcinoma in patients with long-term ingestion of arsenic. J Occup Health. 2005; 47:188-192.

49. Bao L, Shi H. Potential molecular mechanisms for combined toxicity of arsenic and alcohol. J Inorg Biochem. 2010; 104:1229-1233.

50. McNeely SC, Xu X, Taylor BF, Zacharias W, McCabe MJ, States JC. Exit from arsenite-induced mitotic arrest is p53 dependent. Environ Health Perspect. 2006; 114:1401-1406.

51. Udensi UK, Cohly HH, Graham-Evans BE, Ndebele K, Garcia-Reyero N, Nanduri B, Tchounwou PB, Isokpehi RD. Aberrantly expressed genes in HaCaT keratinocytes chronically exposed to arsenic trioxide. Biomark Insights. 2011; 6:7-16.

52. Sasaki A, Oshima Y, Fujimura A. An approach to elucidate potential mechanism of renal toxicity of arsenic trioxide. Exp Hematol. 2007; 35:252-262.

53. Liu J, Xie Y, Ducharme DM, Shen J, Diwan BA, Merrick BA, Grissom SF, Tucker CJ, Paules RS, Tennant R, Waalkes MP. Global gene expression associated with hepatocarcinogenesis in adult male mice induced by in utero arsenic exposure. Environ Health Perspect. 2006; 114:404-411.

54. Chen CJ, Chiou HY, Chiang MH, Lin LJ, Tai TY. Doseresponse relationship between ischemic heart disease mortality and long-term arsenic exposure. Arterioscler Thromb Vasc Biol. 1996; 16:504-510.

55. Argos M, Kibriya MG, Parvez F, Jasmine F, RakibuzZaman M, Ahsan H. Gene expression profiles in peripheral lymphocytes by arsenic exposure and skin lesion status in a Bangladeshi population. Cancer Epidemiol Biomarkers Prev. 2006; 15:1367-1375.

56. Wlodarczyk BJ, Cabrera RM, Hill DS, Bozinov D, Zhu H, Finnell RH. Arsenic-induced gene expression changes in the neural tube of folate transport defective mouse embryos. Neurotoxicology. 2006; 27:547-557.

57. Su PF, Hu YJ, Ho IC, Cheng YM, Lee TC. Distinct gene expression profiles in immortalized human urothelial cells exposed to inorganic arsenite and its methylated trivalent metabolites. Environ Health Perspect. 2006; 114:394-403.

58. Liu ZM, Tseng HY, Yeh BW, Wu WJ, Huang HS. TG-interacting factor mediates arsenic-induced malignant 
transformation of keratinocytes via c-Src/EGFR/AKT/ FOXO3A and redox signalings.Arch Toxicol. 2015; 89:2229-2241.

59. Kitchin KT. Recent advances in arsenic carcinogenesis: modes of action, animal model systems, and methylated arsenic metabolites. Toxicol Appl Pharm. 2001; 172:249-261.

60. Mure K, Uddin AN, Lopez LC, Styblo M, Rossman TG. Arsenite induces delayed mutagenesis and transformation in human osteosarcoma cells at extremely low concentrations. Environ Mol Mutagen. 2003; 41:322-331.

61. Chien CW, Chiang MC, Ho IC, Lee TC. Association of chromosomal alterations with arsenite-induced tumorigenicity of human $\mathrm{HaCaT}$ keratinocytes in nude mice. Environ Health Perspect. 2004; 112:1704-1710.

62. Pi J, Kumagai Y, Sun G, Yamauchi H, Yoshida T, Iso H, Endo A, Yu L, Yuki K, Miyauchi T, Shimojo N. Decreased serum concentrations of nitric oxide metabolites among Chinese in an endemic area of chronic arsenic poisoning in inner Mongolia. Free Radic Biol Med. 2000; 28:1137-1142.

63. Sun Y, Pi J, Wang X, Tokar EJ, Liu J, Waalkes MP. Aberrant cytokeratin expression during arsenic-induced acquired malignant phenotype in human HaCaT keratinocytes consistent with epidermal carcinogenesis. Toxicology. 2009; 262:162-170.

64. Bershadsky AD, Gelfand VI, Vasiliev JM. Multinucleation of transformed cells normalizes their spreading on the substratum and their cytoskeleton structure. Cell Biol Int Rep. 1981; 5:143-150.

65. Bentwich I, Avniel A, Karov Y, Aharonov R, Gilad S, Barad O, Barzilai A, Einat P, Einav U, Meiri E, Sharon E, Spector $\mathrm{Y}$, Bentwich Z. Identification of hundreds of conserved and nonconserved human microRNAs. Nat Genet. 2005; 37:766-770.

66. Garzon R, Calin GA, Croce CM. MicroRNAs in cancer. Annu Rev Med. 2009; 60:167-179.

67. Jeffries CD, Fried HM, Perkins DO. Additional layers of gene regulatory complexity from recently discovered microRNA mechanisms. Int J Biochem Cell Biol. 2010; 42:1236-1242.

68. Sun W, Van Montagu M, Verbruggen N. Small heat shock proteins and stress tolerance in plants. Biochim Biophys Acta. 2002; 1577:1-9.

69. Johnson RM, Goyette GJ, Ravindranath Y, Ho YS. Hemoglobin autoxidation and regulation of endogenous H2O2 levels in erythrocytes. Free Radic Biol Med. 2005; 39:1407-1417.

70. Aldrian S, Trautinger F, Frohlich I, Berger W, Micksche M, Kindas-Mugge I. Overexpression of Hsp27 affects the metastatic phenotype of human melanoma cells in vitro. Cell Stress Chaperones. 2002; 7:177-185.

71. Li GP, Wang H, Lai YK, Chen SC, Lin MC, Lu G, Zhang $\mathrm{JF}$, He XG, Qian CN, Kung HF. Proteomic profiling between CNE-2 and its strongly metastatic subclone S-18 and functional characterization of HSP27 in metastasis of nasopharyngeal carcinoma. Proteomics. 2011; 11:2911-2920.

72. Low FM, Hampton MB, Peskin AV, Winterbourn CC. Peroxiredoxin 2 functions as a noncatalytic scavenger of low-level hydrogen peroxide in the erythrocyte. Blood. 2007; 109:2611-2617.

73. Han YH, Kim SU, Kwon TH, Lee DS, Ha HL, Park DS, Woo EJ, Lee SH, Kim JM, Chae HB, Lee SY, Kim BY, Yoon DY, et al. Peroxiredoxin II is essential for preventing hemolytic anemia from oxidative stress through maintaining hemoglobin stability. Biochem Biophys Res Commun. 2012; 426:427-432.

74. Moore RB, Shriver SK. Protein 7.2b of human erythrocyte membranes binds to calpromotin. Biochem Biophys Res Commun. 1997; 232:294-297.

75. Rinalducci S, D'Amici GM, Blasi B, Zolla L. Oxidative stress-dependent oligomeric status of erythrocyte peroxiredoxin II (PrxII) during storage under standard blood banking conditions. Biochimie. 2011; 93:845-853.

76. Matte A, Bertoldi M, Mohandas N, An X, Bugatti A, Brunati AM, Rusnati M, Tibaldi E, Siciliano A, Turrini F, Perrotta S, De Franceschi L. Membrane association of peroxiredoxin-2 in red cells is mediated by the N-terminal cytoplasmic domain of band 3. Free Radic Biol Med. 2013; 55:27-35.

77. Pallotta V, D'Alessandro A, Rinalducci S, Zolla L. Native protein complexes in the cytoplasm of red blood cells. J Proteome Res. 2013; 12:3529-3546.

78. Chae HZ, Kim HJ, Kang SW, Rhee SG. Characterization of three isoforms of mammalian peroxiredoxin that reduce peroxides in the presence of thioredoxin. Diabetes Res Clin Pract. 1999; 45:101-112.

79. Godoy JR, Funke M, Ackermann W, Haunhorst P, Oesteritz S, Capani F, Elsasser HP, Lillig CH. Redox atlas of the mouse. Immunohistochemical detection of glutaredoxin-, peroxiredoxin-, and thioredoxin-family proteins in various tissues of the laboratory mouse. Biochim Biophys Acta. 2011; 1810:2-92.

80. Noh DY, Ahn SJ, Lee RA, Kim SW, Park IA, Chae HZ. Overexpression of peroxiredoxin in human breast cancer. Anticancer Res. 2001; 21:2085-2090.

81. Leal JF, Ferrer I, Blanco-Aparicio C, HernandezLosa J, Ramon YC, Carnero A, Lleonart ME. S-adenosylhomocysteine hydrolase downregulation contributes to tumorigenesis. Carcinogenesis. 2008; 29:2089-2095.

82. Chou RH, Wen HC, Liang WG, Lin SC, Yuan HW, Wu CW, Chang WS. Suppression of the invasion and migration of cancer cells by SERPINB family genes and their derived peptides. Oncol Rep. 2012; 27:238-245.

83. Zhou B, Zhao J, Liu J, Zhang J, Li J, Wang H. Fluorideinduced oxidative stress is involved in the morphological damage and dysfunction of liver in female mice. Chemosphere. 2015; 139:504-511. 
84. Sarkar S, Mukherjee S, Chattopadhyay A, Bhattacharya S. Low dose of arsenic trioxide triggers oxidative stress in zebrafish brain: expression of antioxidant genes. Ecotox Environ Safe. 2014; 107:1-8.

85. Wang Y, Chaung R, Tung L. (2004). Comparison of the cytotoxicity induced by different exposure to sodium arsenite in two fish cell lines. Aquat Toxicol. 2004; 69:67-79.

86. Spears JW, Weiss WP. Role of antioxidants and trace elements in health and immunity of transition dairy cows. Vet J. 2008; 176:70-76.

87. Franklin CC, Backos DS, Mohar I, White CC, Forman HJ, Kavanagh TJ. Structure, function, and post-translational regulation of the catalytic and modifier subunits of glutamate cysteine ligase. Mol Aspects Med. 2009; 30:86-98.
88. Osorio JS, Ji P, Drackley JK, Luchini D, Loor JJ. Supplemental Smartamine M or MetaSmart during the transition period benefits postpartal cow performance and blood neutrophil function. J Dairy Sci. 2013; 96:6248-6263.

89. Lu SC. Glutathione synthesis. Biochim Biophys Acta. 2013; 1830:3143-3153.

90. Vanderschuren H, Lentz E, Zainuddin I, Gruissem W. Proteomics of model and crop plant species: status, current limitations and strategic advances for crop improvement. J Proteomics. 2013; 93:5-19.

91. Luo Z, Zeng W, Tang W, Long T, Zhang J, Xie X, Kuang Y, Chen M, Su J, Chen X. CD147 interacts with NDUFS6 in regulating mitochondrial complex I activity and the mitochondrial apoptotic pathway in human malignant melanoma cells. Curr Mol Med. 2014; 14:1252-1264. 